\title{
Nutritional, Organoleptic and Keeping Quality of Wheat-Soybean Cookies Supplemented with Pomegranate Peel Powder
}

\author{
Ganeshan Tharshini, Veenu Sangwan* and Suman \\ Department of Foods and Nutrition, CCS Haryana Agricultural University, \\ Hisar, Haryana, India \\ *Corresponding author
}

Ke y w o r d s
$\begin{aligned} & \text { Wheat, Soybean, } \\ & \text { Pomegranate peel } \\ & \text { powder, } \\ & \text { Supplemented }\end{aligned}$
Article Info
$\begin{aligned} & \text { Accepted: } \\ & \text { 06 December } 2017 \\ & \text { Available Online: } \\ & \text { 10 January } 2018\end{aligned}$

\section{Introduction}

Value addition is receiving the prime focus among food scientists and researchers not only to increase the alternative uses of cereals, millets and pulses but also to enhance the nutritive value and health potential of developed products. Soybean (Glycine max) is an important source of dietary protein (about $40 \%$ ) of good nutritional quality and a high oil content (about 20\%) together with numerous beneficial nutrients, bioactive factors and phytochemicals which make it the crop of choice for improving the diets of millions of
The present study highlights the potential for utilization of pomegranate peel powder to increase the nutritional, organoleptic and keeping quality of wheat and soybean based soybean flour ratio was kept constant (10 per cent) while wheat flour was comegranate peel powder at 5, 7.5 and 10 per cent levels in cookies. All the cookies were 8.89 and 20.34 per cent, respectively which significantly $(\mathrm{P} \leq 0.05)$ increased to 10.79 and 21.72 per cent, respectively in Type I cookies. It was found that crude fibre (4.21 per cent) and ash (2.28 per cent) were highest in Type III cookies. Total dietary fibre ntent of control cookies was 8.43 per cent and that of Type I, Type II and Type III cookies was $9.21,9.53$ and 9.88 per cent, respectively which were significantly $(\mathrm{P} \leq 0.05)$ that of control. The soybean flour and pomegranate peel powder supplemented cookies possessed significantly $(\mathrm{p} \leq 0.05)$ higher calcium, phosphorus, iron, zinc and magnesium contents than control cookies. The cookies were organoleptically acceptable upto 90 days in air tight containers at room temperature. 
2014). Pomegranate peel is a nutrient rich byproduct and possesses apparent wound healing properties, immune modulatory activity, antibacterial activity, anti-atherosclerotic and anti-oxidative capacities (Ibrahium, 2010; Akhtar et al., 2015). Intelligent utilization of pomegranate peel powder and peel extracts has been successfully experienced in various food preparations including edible oils, bakery products, jellies and meat and meat products and yoghurt (Naveena et al., 2008; Kanatt et al., 2010; Devatkal et al., 2012; Altunkaya et al., 2013; El-Batawy, 2014). The supplementation of wheat based bakery products with both soybean and pomegranate peel powder will help in improving their amino acid pattern and nutritional value and will make available functional foods. The present study was undertaken to assess the effect of supplementation, of wheat-soybean cookies, with pomegranate peel powder on their nutritional, organoleptic and keeping quality.

\section{Materials and Methods}

\section{Procurement and processing of raw material}

The wheat grains (WH-1142) were cleaned and ground in an electric grinder (Cyclotec, $\mathrm{M} / \mathrm{s}$ Tecator, Hoganas, Sweden) and flour obtained was sieved through a 60 mesh sieve and packed in airtight plastic containers for further use.

The pomegranate fruits were washed thoroughly, peeled and the fruit peels were cut into small pieces and dried in open air under shade. Dried peel was converted into fine powder form and packed in airtight plastic container for further use Soybean (Glycine max) flour along with other ingredients required for the development of baked products was purchased from the local market of Hisar.

\section{Preparation of cookies}

\section{Method}

Wheat flour, soybean flour and pomegranate peel powder were sieved together.

Butter and sugar were creamed. Ammonium bicarbonate and baking soda were added and mixed well with creamed butter and sugar. Egg was added to the creamed mixture and mixed.

In the above mixture sieved flour was added and dough was prepared. Dough was placed for conditioning for 30 minutes in refrigerator. The dough was kneaded again and rolled into sheet and molded to round shape and placed in baking trays.

Baking was done, in preheated oven, at $160^{\circ} \mathrm{C}$ for about 25 minutes or till brown colour.

\section{Organoleptic evaluation of cookies}

Cookies were subjected to sensory evaluation with respect to color, appearance, aroma, texture, taste and overall acceptability by a panel of 10 semi trained judges, using 9 point hedonic scale.

\section{Nutritional evaluation of pomegranate peel powder and cookies}

Moisture content, ash, crude fat, protein and fibre was determined by employing the standard method of analysis (AOAC, 2000). Total, soluble and insoluble dietary fiber constituents were determined by the enzymatic method given by Furda (1981). Calcium, iron, zinc and magnesium in acid digested samples were determined by Atomic Absorption Spectrophotometer according to the method of Lindsey and Norwell (1969). Phosphorus was determined colorimetrically by using the method of Chen et al., (1956). 
Shelf life studies of cookies supplemented with pomegranate peel powder

\section{Organoleptic evaluation and fat acidity}

The fat acidity was determined by the standard method of analysis (AOAC, 2000).

\section{Statistical analysis}

Mean, standard error and CD (critical difference) were calculated for analysis of data (Sheoran and Pannu, 1999).

\section{Results and Discussion}

\section{Organoleptic acceptability of cookies}

The data on organoleptic acceptability of cookies is presented in Table 1. The colour score of the control cookies was 8.00 (liked very much) while that of soybean flour and pomegranate peel powder supplemented cookies were 7.90 (liked very much) at $85: 10: 5.0, \quad 7.70$ (liked very much) at $82.5: 10: 7.5$ and 7.90 (liked very much) at 80:10:10 levels of substitution of wheat flour with soybean flour and pomegranate peel powder. The appearance scores of cookies prepared from wheat flour supplemented with soybean flour and pomegranate peel powder were 8.00, 7.50 and 7.90 in Type I, II and III cookies, respectively and also fell in the category' liked very much'. The aroma scores of wheat flour cookies supplemented with soybean flour and pomegranate peel powder were 8.00 (liked very much) at 85:10:5 level of supplementation while at 85:10:5 level of substitution, it was 8.10 and 8.00 at 80:10:10 level of supplementation. The textural score of the control cookies was 7.80 and was in the category of 'liked very much'. With the incorporation of soybean flour and pomegranate peel powder there was a nonsignificant increase in the mean scores of texture. Cookies prepared from wheat flour supplemented with soybean flour and pomegranate peel powder at 85:10:5, 82.5:10:7.5 and 80:10:10 level of incorporation had texture score of 7.90, 8.10 and 8.20 , respectively which were found in the category of 'liked very much'. The score for the taste of the control cookies was 7.70 (liked very much) while the mean scores of taste in Type I, II and III cookies was 8.05, 7.75 and 7.85 , respectively. The scores were in the category of 'liked very much'. The control cookies obtained 7.90 mean score for overall acceptability which was in the category 'liked very much'. Mean scores of overall acceptability in cookies supplemented with soybean flour and pomegranate peel powder were $7.97,7.83$ and 7.85 at 85:10:5, 82.5:10:7.5 and 80:10:10 level of supplementation, respectively which fell in the category 'liked very much'. All types of cookies were organoleptically acceptable and their overall acceptability scores were in the category 'liked very much'. The results of the present study are in the agreement with those of Mahmoodi (2008), Ndife et al., (2011) and Dhore (2011) who also reported that overall acceptability of control biscuits and supplemented biscuits fell in the category of 'liked very much'.

\section{Nutritional composition of cookies}

Protein and fat contents in control cookies were 8.89 and 20.34 per cent, respectively which significantly $(\mathrm{P} \leq 0.05)$ increased to 10.79 and 21.72 per cent, respectively in Type I cookies (Table 2). The protein and fat contents were 10.45 and 21.90 per cent and 10.13 and 22.11 per cent in Type II and Type III cookies, respectively, which were also significantly $(\mathrm{P} \leq 0.05)$ higher than that of control cookies. Crude fibre and ash contents in control cookies were 1.02 and 1.23 per cent, respectively which significantly $(\mathrm{P} \leq 0.05)$ increased to 2.18 and 2.00 per cent in Type I cookies, respectively. 
Table.4 Total minerals of cookies (mg/100g on dry matter basis)

\begin{tabular}{|c|c|c|c|c|c|}
\hline Cookies & Calcium & Phosphorus & Iron & Zinc & Magnesium \\
\hline Control $(\mathbf{1 0 0 \%}$ WF) & $49.98 \pm 0.94$ & $168.75 \pm 5.61$ & $2.84 \pm 0.04$ & $1.16 \pm 0.02$ & $72.22 \pm 3.66$ \\
\hline $\begin{array}{c}\text { Type I } \\
\text { (WF:SBF:PPP::85:10:5) }\end{array}$ & $61.07 \pm 1.33$ & $218.75 \pm 3.54$ & $3.47 \pm 0.02$ & $1.29 \pm 0.01$ & $88.72 \pm 0.71$ \\
\hline $\begin{array}{c}\text { Type II } \\
\text { (WF:SBF:PPP::82.5:10:7.5) }\end{array}$ & $62.16 \pm 0.47$ & $213.54 \pm 3.34$ & $3.41 \pm 0.03$ & $1.24 \pm 0.01$ & $89.64 \pm 1.34$ \\
\hline $\begin{array}{c}\text { Type III } \\
\text { (WF:SBF:PPP::80:10:10) }\end{array}$ & $63.25 \pm 0.42$ & $186.54 \pm 4.29$ & $3.37 \pm 0.02$ & $1.21 \pm 0.02$ & $90.75 \pm 0.19$ \\
\hline CD (P<0.05) & 2.62 & 6.35 & 0.25 & 0.02 & 2.45 \\
\hline
\end{tabular}

Values are mean \pm SE of three independent determinations

$\mathrm{WF}=$ Wheat Flour, $\mathrm{SBF}=$ Soybean Flour and PPP $=$ Pomegranate Peel Powder

Table.5 Effect of storage period on mean scores of sensory characteristics of cookies

\begin{tabular}{|c|c|c|c|c|c|c|c|c|}
\hline \multirow{2}{*}{$\begin{array}{l}\text { Supplementation } \\
\text { Level }(\%)\end{array}$} & \multicolumn{8}{|c|}{ Storage period (days) } \\
\hline & 0 & 15 & 30 & 45 & 60 & 75 & 90 & Mean \\
\hline \multicolumn{9}{|c|}{ Colour } \\
\hline Control (100\% WF) & $8.00 \pm 0.15$ & $7.80 \pm 0.25$ & $7.70 \pm 0.25$ & $7.60 \pm 0.16$ & $7.60 \pm 0.16$ & $7.50 \pm 0.22$ & $7.10 \pm 0.23$ & $7.61 \pm 0.28$ \\
\hline Type I (WF:SBF:PPP::85:10:5) & $7.90 \pm 0.18$ & $7.90 \pm 0.18$ & $7.50 \pm 0.20$ & $7.40 \pm 0.31$ & $7.40 \pm 0.37$ & $7.30 \pm 0.26$ & $6.70 \pm 0.21$ & $7.44 \pm 0.41$ \\
\hline Type II (WF:SBF:PPP::82.5:10:7.5) & $7.70 \pm 0.26$ & $7.60 \pm 0.31$ & $7.50 \pm 0.22$ & $7.40 \pm 0.34$ & $7.30 \pm 0.15$ & $7.00 \pm 0.21$ & $6.70 \pm 0.3$ & $7.31 \pm 0.35$ \\
\hline Type III (WF:SBF:PPP::80:10:10) & $7.90 \pm 0.23$ & $7.70 \pm 0.213$ & $7.30 \pm 0.37$ & $7.20 \pm 0.17$ & $7.20 \pm 0.26$ & $7.00 \pm 0.21$ & $6.80 \pm 0.25$ & $7.30 \pm 0.38$ \\
\hline Mean & 7.88 & 7.75 & 7.50 & 7.40 & 7.38 & 7.20 & 6.82 & \\
\hline \multicolumn{9}{|c|}{ Appearance } \\
\hline Control $(100 \% \mathrm{WF})$ & $8.10 \pm 0.18$ & $7.80 \pm 0.25$ & $7.60 \pm 0.16$ & $7.60 \pm 0.16$ & $7.40 \pm 0.16$ & $7.40 \pm 0.22$ & $6.80 \pm 0.25$ & $7.53 \pm 0.40$ \\
\hline Type I (WF:SBF:PPP::85:10:5) & $8.00 \pm 0.21$ & $7.80 \pm 0.20$ & $7.50 \pm 0.17$ & $7.40 \pm 0.31$ & $7.30 \pm 0.25$ & $7.25 \pm 0.17$ & $6.60 \pm 0.22$ & $7.41 \pm 0.45$ \\
\hline Type II (WF:SBF:PPP::82.5:10:7.5) & $7.60 \pm 0.27$ & $7.50 \pm 0.27$ & $7.40 \pm 0.34$ & $7.20 \pm 0.20$ & $7.20 \pm 0.20$ & $7.10 \pm 0.18$ & $6.70 \pm 0.21$ & $7.24 \pm 0.29$ \\
\hline Type III (WF:SBF:PPP::80:10:10) & $7.90 \pm 0.23$ & $7.60 \pm 0.22$ & $7.20 \pm 0.33$ & $7.20 \pm 0.20$ & $7.20 \pm 0.20$ & $7.20 \pm 0.21$ & $6.80 \pm 0.25$ & $7.30 \pm 0.35$ \\
\hline Mean & 7.90 & 7.68 & 7.42 & 7.35 & 7.38 & 7.24 & 6.72 & \\
\hline \multicolumn{9}{|c|}{ Aroma } \\
\hline Control (100\% WF) & $7.90 \pm 0.10$ & $7.75 \pm 0.29$ & $7.60 \pm 0.16$ & $7.50 \pm 0.31$ & $7.30 \pm 0.30$ & $7.20 \pm 0.25$ & $6.70 \pm 0.30$ & $7.42 \pm 0.39$ \\
\hline Type I (WF:SBF:PPP::85:10:5) & $8.00 \pm 0.15$ & $7.75 \pm 0.33$ & $7.70 \pm 0.21$ & $7.55 \pm 0.19$ & $7.50 \pm 0.17$ & $7.10 \pm 0.23$ & $6.70 \pm 0.30$ & $7.47 \pm 0.44$ \\
\hline Type II (WF:SBF:PPP::82.5:10:7.5) & $8.10 \pm 0.18$ & $7.70 \pm 0.26$ & $7.50 \pm 0.22$ & $7.50 \pm 0.22$ & $7.45 \pm 0.30$ & $7.10 \pm 0.23$ & $6.70 \pm 0.30$ & $7.44 \pm 0.44$ \\
\hline Type III (WF:SBF:PPP::80:10:10) & $8.20 \pm 0.20$ & $7.80 \pm 0.20$ & $7.40 \pm 0.16$ & $7.35 \pm 0.30$ & $7.20 \pm 0.20$ & $7.00 \pm 0.3$ & $6.50 \pm 0.34$ & $7.35 \pm 0.55$ \\
\hline Mean & 8.05 & 7.75 & 7.55 & 7.48 & 7.39 & 7.10 & 6.65 & \\
\hline \multicolumn{9}{|c|}{ Texture } \\
\hline Control $(100 \% \mathrm{WF})$ & $7.80 \pm 0.20$ & $7.70 \pm 0.30$ & $7.60 \pm 0.16$ & $7.50 \pm 0.22$ & $7.40 \pm 0.221$ & $7.40 \pm 0.221$ & $6.30 \pm 0.26$ & $7.39 \pm 0.50$ \\
\hline Type I (WF:SBF:PPP::85:10:5) & $7.90 \pm 0.18$ & $7.70 \pm 0.34$ & $7.60 \pm 0.27$ & $7.50 \pm 0.17$ & $7.50 \pm 0.17$ & $7.20 \pm 0.20$ & $6.30 \pm 0.34$ & $7.39 \pm 0.52$ \\
\hline Type II (WF:SBF:PPP::82.5:10:7.5) & $8.10 \pm 0.18$ & $7.50 \pm 0.22$ & $7.40 \pm 0.31$ & $7.40 \pm 0.31$ & $7.40 \pm 0.22$ & $7.00 \pm 0.21$ & $6.40 \pm 0.27$ & $7.31 \pm 0.52$ \\
\hline Type III (WF:SBF:PPP::80:10:10) & $8.00 \pm 0.21$ & $7.70 \pm 0.21$ & $7.60 \pm 0.27$ & $7.15 \pm 0.29$ & $7.10 \pm 0.23$ & $7.10 \pm 0.28$ & $6.30 \pm 0.34$ & $7.28 \pm 0.55$ \\
\hline Mean & 7.95 & 7.65 & 7.55 & 7.39 & 7.35 & 7.18 & 6.32 & \\
\hline \multicolumn{9}{|c|}{ Taste } \\
\hline Control (100\% WF) & $7.70 \pm 0.26$ & $7.60 \pm 0.16$ & $7.60 \pm 0.27$ & $7.40 \pm 0.16$ & $7.40 \pm 0.27$ & $7.30 \pm 0.26$ & $6.60 \pm 0.27$ & $7.37 \pm 0.37$ \\
\hline Type I (WF:SBF:PPP::85:10:5) & $8.05 \pm 0.19$ & $7.90 \pm 0.18$ & $7.60 \pm 0.37$ & $7.50 \pm 0.17$ & $7.50 \pm 0.17$ & $7.30 \pm 0.21$ & $6.40 \pm 0.31$ & $7.46 \pm 0.53$ \\
\hline Type II (WF:SBF:PPP::82.5:10:7.5) & $7.75 \pm 0.20$ & $7.70 \pm 0.26$ & $7.40 \pm 0.31$ & $7.30 \pm 0.30$ & $7.20 \pm 0.20$ & $7.00 \pm 0.21$ & $6.70 \pm 0.34$ & $7.29 \pm 0.37$ \\
\hline Type III (WF:SBF:PPP::80:10:10) & $7.85 \pm 0.24$ & $7.60 \pm 0.22$ & $7.40 \pm 0.22$ & $7.20 \pm 0.39$ & $7.20 \pm 0.29$ & $7.00 \pm 0.29$ & $6.40 \pm 0.31$ & $7.24 \pm 0.46$ \\
\hline Mean & 7.84 & 7.70 & 7.50 & 7.35 & 7.33 & 7.15 & 6.53 & \\
\hline \multicolumn{9}{|c|}{ Overall Acceptability } \\
\hline Control $(100 \%$ WF $)$ & $7.90 \pm 0.13$ & $7.73 \pm 0.26$ & $7.58 \pm 0.15$ & $7.50 \pm 0.24$ & $7.44 \pm 0.15$ & $7.40 \pm 0.23$ & $6.70 \pm 0.24$ & $7.46 \pm 0.38$ \\
\hline Type I (WF:SBF:PPP::85:10:5) & $7.97 \pm 0.13$ & $7.78 \pm 0.19$ & $7.61 \pm 0.29$ & $7.50 \pm 0.17$ & $7.44 \pm 0.23$ & $7.24 \pm 0.21$ & $6.54 \pm 0.25$ & $7.44 \pm 0.46$ \\
\hline Type II (WF:SBF:PPP::82.5:10:7.5) & $7.83 \pm 0.14$ & $7.58 \pm 0.23$ & $7.45 \pm 0.29$ & $7.36 \pm 0.17$ & $7.34 \pm 0.27$ & $7.04 \pm 0.19$ & $6.64 \pm 0.26$ & $7.32 \pm 0.38$ \\
\hline $\begin{array}{c}\text { Type III } \\
\text { (WF:SBF:PPP::80:10:10) }\end{array}$ & $7.85 \pm 0.17$ & $7.66 \pm 0.19$ & $7.34 \pm 0.19$ & $7.24 \pm 0.32$ & $7.22 \pm 0.21$ & $7.06 \pm 0.25$ & $6.56 \pm 0.28$ & $7.28 \pm 0.42$ \\
\hline Mean & 7.89 & 7.69 & 7.50 & 7.40 & 7.36 & 7.18 & 6.61 & \\
\hline
\end{tabular}

Values are mean \pm SE of ten observations; WF $=$ Wheat Flour, SBF $=$ Soybean Flour and PPP $=$ Pomegranate Peel Powder 
Int.J.Curr.Microbiol.App.Sci (2018) 7(1): 803-810

Table.6 Effect of storage period on fat acidity (mg KOH/100g) of cookies (on dry weight basis)

\begin{tabular}{|c|c|c|c|c|c|c|c|c|}
\hline \multirow{2}{*}{$\begin{array}{c}\text { Supplementation } \\
\text { level }(\%)\end{array}$} & \multicolumn{7}{|c|}{ Storage period (days) } & \multirow[t]{2}{*}{ Mean } \\
\hline & $\mathbf{0}$ & 15 & 30 & 45 & 60 & 75 & 90 & \\
\hline Control (100\% WF) & $32.34 \pm 0.33$ & $36.67 \pm 0.57$ & $42.34 \pm 0.33$ & $47.67 \pm 0.33$ & $52.67 \pm 0.67$ & $59.33 \pm 1.20$ & $67.67 \pm 0.67$ & $48.38 \pm 12.53$ \\
\hline Type I (WF:SBF:PPP::85:10:5) & $36.67 \pm 0.89$ & $41.34 \pm 0.89$ & $47.34 \pm 0.33$ & $52.00 \pm 0.22$ & $56.67 \pm 1.20$ & $65.67 \pm 0.67$ & $72.33 \pm 0.89$ & $53.14 \pm 12.80$ \\
\hline Type II (WF:SBF:PPP::82.5:10:7.5) & $35.34 \pm 1.20$ & $41.00 \pm 0.82$ & $46.34 \pm 0.67$ & $51.33 \pm 1.20$ & $55.33 \pm 1.21$ & $64.33 \pm 0.33$ & $71.67 \pm 0.58$ & $52.19 \pm 13.00$ \\
\hline Type III (WF:SBF:PPP::80:10:10) & $34.67 \pm 0.58$ & $39.67 \pm 0.33$ & $45.33 \pm 0.58$ & $50.67 \pm 0.33$ & $54.67 \pm 0.22$ & $63.33 \pm 0.33$ & $69.67 \pm 0.58$ & $51.14 \pm 12.69$ \\
\hline Mean & 34.75 & 39.67 & 45.83 & 50.42 & 54.83 & 63.14 & 70.33 & \\
\hline $\mathrm{CD}(\mathrm{P} \leq 0.05)$ & \multicolumn{2}{|c|}{ Period : 0.59} & \multicolumn{3}{|c|}{ Supplementation level : 0.45} & \multicolumn{3}{|c|}{ Period $\times$ Supplementation level : 1.18} \\
\hline
\end{tabular}

Values are mean \pm SE of three independent determinations

$\mathrm{WF}=$ Wheat Flour, $\mathrm{SBF}=$ Soybean Flour and PPP $=$ Pomegranate Peel Powder

The crude fibre and ash contents were 3.53 and 2.14 per cent and 4.21 and 2.28 per cent in Type II and Type III cookies, respectively. The supplemented cookies had significantly $(\mathrm{P} \leq 0.05)$ higher contents of moisture, protein, fat, crude fibre and ash as compared to control cookies. It was found that protein content was highest in Type I cookies (10.79 per cent) while fat (22.11 per cent), crude fibre (4.21 per cent) and ash ( 2.28 per cent) were highest in Type III cookies. It was observed that as the level of substitution with pomegranate peel powder increased there was a significant $(\mathrm{P} \leq 0.05)$ increase in fat, crude fibre and ash contents of value added cookies. The data pertaining to dietary fibre content of cookies is presented in Table 3. Total dietary fibre content of control cookies was 8.43 per cent, and that of Type I, Type II and Type III cookies was $9.21,9.53$ and 9.88 per cent, respectively which were significantly $(\mathrm{P} \leq 0.05)$ higher than that of control. Soluble dietary fibre and insoluble dietary fibre contents of control cookies were 1.85 and 6.58 per cent respectively which also increased significantly $(\mathrm{P} \leq 0.05)$ in value added cookies with the increment in supplementation of wheat flour with soybean flour and pomegranate peel powder at all the levels i.e. 85:10:5 (2.15 and 7.06 per cent, respectively), 82.5:10:7.5 (2.35 and 7.18 per cent, respectively) and 80:10:10 (2.53 and 7.35 per cent, respectively) levels. The nutritional value of supplemented value added products is always higher than control products (Sangwan and Dahiya, 2013; Ismail et al., 2014; Pandey and Sangwan, 2016a).

\section{Total minerals}

The result of total mineral contents of cookies is presented in Table 4. The control cookies contained 49.98, 168.75, 2.84, 1.16 and 72.22 $\mathrm{mg} / 100 \mathrm{~g}$ of calcium, phosphorus, iron, zinc and magnesium, respectively which were significantly $(p \leq 0.05)$ lower than that of soybean flour and pomegranate peel powder supplemented cookies. Type I cookies possessed 61.07, 218.75, 3.47, 1.29 and 88.72 $\mathrm{mg} / 100 \mathrm{~g}$ calcium, phosphorus, iron, zinc and magnesium, respectively while Type II cookies contained62.16, 213.54, 3.41, 1.24 and $89.64 \mathrm{mg} / 100 \mathrm{~g}$, calcium, phosphorus, iron, zinc and magnesium, respectively. Type III cookies contained 186.54 and 1.21 $\mathrm{mg} / 100 \mathrm{~g}$, phosphorus and zinc, respectively which were significantly $(p \leq 0.05)$ lower than Type I and Type II cookies. However there was a non-significant difference in the calcium, iron and magnesium contents of all types of cookies at 5 to 10 per cent level of substitution with pomegranate peel powder. Similar findings were also reported by other workers (Pandey and Sangwan, 2016b; Pandey and Sangwan, 2016c) that value added products possessed higher mineral contents compared to control. The increase in mineral contents of value added products might be due to high contents of calcium, phosphorus, magnesium, iron and zinc in 
soybean flour as compared to wheat flour and pomegranate peel powder. Moreover pomegranate peel powder also possessed higher calcium and magnesium contents than wheat flour.

\section{Shelf life studies of supplemented cookies}

\section{Organoleptic evaluation and fat acidity}

Stored products were studied for their sensory characteristics at an interval of 15 days upto acceptability by a panel of 10 semi-trained judges using nine-point Hedonic Scale (Table 5). The score of appearance of all types of cookies was in the category of 'liked moderately' to 'liked very much', upto 90 days of storage. The score of aroma of all types of cookies was in the category of 'liked moderately' to 'liked very much', during three months of storage. The scores of texture of control cookies, Type I, Type II and Type III cookies changed from 7.80 (zero day) to $6.30\left(90^{\text {th }}\right.$ day), 7.90 (zero day) to $6.30\left(90^{\text {th }}\right.$ day), 8.10 (zero day) to $6.40\left(90^{\text {th }}\right.$ day) and 8.00 (zero day) to $6.30\left(90^{\text {th }}\right.$ day), respectively. All types of cookies were organoleptically acceptable and fell in category of 'liked very much' to 'liked slightly' during three months of storage. However on mean basis all types of cookies were acceptable upto 90 days of storage and fell in the category of 'liked moderately'. The fat acidity of Type I, Type II and Type III cookies increased from 36.67 to $72.33,35.34$ to 71.67 and 34.67 to $69.67 \mathrm{mg} \mathrm{KOH} / 100 \mathrm{~g}$, respectively during zero to 90 days of storage (Table 6). At the same time it was also observed that on the mean basis the fat acidity of Type III (51.14 mg KOH/100g) cookies was significantly lower than that of Type II (52.19 $\mathrm{mg} \mathrm{KOH} / 100 \mathrm{~g}$ ) and maximum fat acidity content was found in Type I $(53.14 \mathrm{mg}$ $\mathrm{KOH} / 100 \mathrm{~g}$ ) cookies. Thus indicating that as the level of supplementation with pomegranate peel powder increased in cookies the fat acidity content decreased. From the present study it can be concluded that there is great scope for utilization of pomegranate peels to develop value added cookies having good shelf life.

\section{References}

A.O.A.C. 2000. Official Methods of Analysis of Association of Official Analytical Chemists. Washington, D.C.

Akhtar, S., Ismail, T., Fraternale, D. and Sestili, P. 2015. Pomegranate peel and peel extracts: chemistry and food features. Food Chemistry. 174: 417425.

Ali, N. 2010. Soybean processing and utilization. The Soybean Botany, Production and Uses. (Ed. G. Singh). CABI International, pp. 345.

Altunkaya, A., Hedegaard, R.V., Brimer, L., Gokmen, V. and Skibsted, L.H. 2013. Antioxidant capacity versus chemical safety of wheat bread enriched with pomegranate peel powder. Food Function. 4:722-727.

Chen, P. S., Tosibara, T. Y. and Warner, H. 1956. Micro determination of phosphorus. Annals of Chemistry. 28: 1756-1759.

Devatkal, S.K., Thorat, P. and Manjunatha, M. 2012. Effect of vacuum packaging and pomegranate peel extract on quality aspects of ground goat meat and nuggets. Journal of Food Science and Technology. DOI 10.1007/s13197-0120753-5.

Dhore, K. R. 2011. Sensory evaluation of sorghum chakali enriched with different levels of soyabean flours. International Research Journals. 3(31): 50-51.

El-Batawy, O.I, Ashoush, I.S. and Mehanna, N.S. 2014. Impact of mango and pomegranate peels supplementation on quality characteristics of yoghurt with 
or without whey powder. World J. Dairy \& Food Sciences. 9 (1): 57-65.

Furda, I. 1981. Simultaneous analysis of soluble and insoluble dietary fibre. The Analysis of Dietary Fibre in Food (Eds. W.P.T. James and O. Theander), Marcel Dekker, New York. pp. 163-172.

Ibrahium, M.I. 2010. Efficiency of pomegranate peel extract as antimicrobial, antioxidant and protective agents.World J. of Agricultural Sciences. 6 (4): 338-344.

Ismail, T., Akhtar, S., Muhammad, R. and Amir, I. 2014. Effect of pomegranate peel supplementation on nutritional, organoleptic and stability properties of cookies. Journal of Food Science and Nutrition. 65(6): 661-666.

Jain, S., Rai, R., Upadhyaya, A.R. and Malhotra, G. 2014. Punicagranatum: A natural and recent approach towards dental problem. International Journal of Pharm Research Science. 2: 1-6.

Kanatt, S.R., Chander, R. and Sharma, A. 2010. Antioxidant and antimicrobial activity of pomegranate peel extract improve shelf life of chicken products. International Journal of Food Science and Technology. 45: 216-222.

Lindsey, W. L., and Norwell, M.A. 1969. A new DPTA-TEA Soil test for zinc and iron. Agronomy Abstract. 61: 84-89.

Mahmoodi, M. A. 2008. Effect of fortification of defatted soy flour on sensory and rheological properties of wheat bread. International Journal of Food Science and Technology. 43(9): 1693-1698.

Naveena, B.M., Sen, A.R., Kingsly, R.P., Singh D.B. and Kondaiah, N. 2008.
Antioxidant activity of pomegranate rind powder extract in cooked chicken patties. International Journal of Food Science and Technology.43: 18071812.

Ndife, J., Abdulraheem, L. O. and Zakari, U. M. 2011. Evaluation of the nutritional and sensory quality of functional breads produced from whole wheat and soya bean flour blends. African Journal of Food Science. 5(8): 466-472.

Pandey, L. and Sangwan, V. 2016a. Keeping quality of sorghum soybean supplemented wheat flour ladoos. International Journal of Advanced Nutritional and Health Science. 4(1): 196-202.

Pandey, L. and Sangwan, V. 2016b. Nutritional composition of value added cake developed from newly released wheat: a comparative study. Annals of Agri-Bio Research. 21(1): 79-82.

Pandey, L. and Sangwan, V. 2016c. Total and available mineral contents of wheatsorghum- soybean flour blend sev. Annals of Biology. 32(1): 94-96.

Sangwan, V. and Dahiya, S.2013. Physicochemical and nutritional properties of wheat-sorghum-soybean composite flours and their biscuits Asian J. Dairy and Food Res. 32 (1): 65 - 70, 2013

Sheoran, O. P and Pannu, R. S. 1999. Statistical software package for agricultural research workers in recent advances in information theory, Statistics and Computer application. (Eds. DS. Hooda and R.C. Hasija) pp.139-143.

\section{How to cite this article:}

Ganeshan Tharshini, Veenu Sangwan and Suman. 2018. Nutritional, Organoleptic and Keeping Quality of Wheat-Soybean Cookies Supplemented with Pomegranate Peel Powder. Int.J.Curr.Microbiol.App.Sci. 7(01): 803-810. doi: https://doi.org/10.20546/ijcmas.2018.701.098 